\title{
EVALUATION OF MUSCLE STRENGTH IN MEDULLAR INJURY: A LITERATURE REVIEW
}

\author{
AVALIAÇÃO DA FORÇA MUSCULAR NA LESÃO MEDULAR: UMA REVISÃO DA LITERATURA \\ EVALUACIÓN DE LA FUERZA MUSCULAR EN LA LESIÓN MEDULAR: UNA REVISIÓN \\ DE LA LITERATURA
}

\author{
Tânia Valdameri Capelari ${ }^{1}$, Jéssica Saccol Borin ${ }^{1}$, Melissa Grigol ${ }^{2}$, Raquel Saccan ${ }^{3}$, Franciele Zardo ${ }^{4}$, Fernanda Cechetti ${ }^{1,4}$ \\ 1. Graduate Program in Rehabilitation Science of the Universidade Federal de Ciências da Saúde de Porto Alegre, Rio Grande do Sul, RS, Brazil. \\ 2. Pontifícia Universidade Católica do Rio Grande do Sul, RS, Brazil. \\ 3. Universidade de Caxias do Sul, Caxias do Sul, Rio Grande do Sul, RS, Brazil. \\ 4. Universidade Federal de Ciências da Saúde de Porto Alegre, Rio Grande do Sul, RS, Brazil.
}

\begin{abstract}
Objective: To identify the tools used to evaluate muscle strength in subjects with spinal cord injury in both clinical practice and scientific research. Methods: Initially, the literature review was carried out to identify the tools used in scientific research. The search was conducted in the following databases: Virtual Health Library (VHL), Pedro, and PubMed. Studies published between 1990 and 2016 were considered and selected, depicting an evaluation of muscle strength as an endpoint or for characterization of the sample. Next, a survey was carried out with physiotherapists to identify the instruments used for evaluation in clinical practice, and the degree of satisfaction of professionals with respect to them. Results: 495 studies were found; 93 were included for qualitative evaluation. In the studies, we verified the use of manual muscle test with different graduation systems, isokinetic dynamometer, hand-held dynamometer, and manual dynamometer. In clinical practice, the manual muscle test using the motor score recommended by the American Spinal Cord Injury Association was the most used method, despite the limitations highlighted by the physiotherapists interviewed. Conclusion: In scientific research, there is great variation in the methods and tools used to evaluate muscle strength in individuals with spinal cord injury, differently from clinical practice. The tools available and currently used have important limitations, which were highlighted by the professionals interviewed. No instrument depicts direct relationship of muscle strength and functionality of the subject. There is no consensus as to the best method for assessing muscle strength in spinal cord injury, and new instruments are needed that are specific for use in this population.
\end{abstract}

Keywords: Muscle strength; Physical examination; Spinal cord.

\section{RESUMO}

Objetivo: Identificar quais são os instrumentos utilizados para avaliação de força muscular em sujeitos com lesão medular tanto na prática clínica, quanto em pesquisas científicas. Métodos: Inicialmente, realizou-se a revisão da literatura para identificação dos instrumentos utilizados em pesquisas científicas. A busca foi feita nas bases Biblioteca Virtual em Saúde (BVS), PEdro e PubMed. Foram considerados estudos publicados entre 1990 e 2016 e selecionados os que apresentaram a avaliação da força muscular como desfecho ou para caracterização da amostra. A seguir, foi realizado um levantamento junto a fisioterapeutas para identificar quais são os instrumentos utilizados para avaliação na prática clínica, e qual o grau de satisfação dos profissionais com relação a eles. Resultados: Foram encontrados 495 artigos; 93 foram incluídos para avaliação qualitativa. Nos estudos, verificou-se o uso do teste muscular manual com diferentes sistemas de graduação, do dinamômetro isocinético, do dinamômetro portátil e do dinamômetro manual. Na prática clínica, o teste muscular manual com uso do escore motor recomendado pela American Spinal Cord Injury Association foi o método mais utilizado, apesar das limitações destacadas pelos fisioterapeutas entrevistados. Conclusão: Nas pesquisas cientificas, é grande a variação de métodos e instrumentos utilizados para avaliação da força muscular em sujeitos com lesão medular, diferentemente da prática clínica. Os instrumentos disponíveis e utilizados atualmente apresentam importantes limitações, que foram destacadas pelos profissionais entrevistados. Nenhum instrumento apresenta a relação direta da força muscular com a funcionalidade do sujeito. Não há consenso sobre qual o melhor método para avaliação da força muscular na lesão medular, e são necessários novos instrumentos que sejam específicos para uso nessa população.

Descritores: Força muscular; Exame físico; Medula espinhal.

\section{RESUMEN}

Objetivo: Identificar cuáles son los instrumentos utilizados para evaluar la fuerza muscular en sujetos con lesión medular tanto en la práctica clínica, como en investigaciones científicas. Métodos: Inicialmente, se realizó la revisión de la literatura para identificar los instrumentos utilizados en investigaciones científicas. La búsqueda fue hecha en las bases de Biblioteca Virtual en Salud (BVS), PEdro y PubMed. Se consideraron estudios publicados entre 1990 y 2016 y se seleccionaron los que presentaron la evaluación de la fuerza muscular como resultado o para caracterización de la muestra. A continuación, se realizó un levantamiento junto a fisioterapeutas para identificar cuáles son los instrumentos utilizados para evaluación en la práctica clínica y cuál es el grado de satisfacción de los profesionales con relación a ellos. Resultados: Se han encontrado 495 artículos; 93 se incluyeron para la evaluación cualitativa. En los estudios se verificó el uso del test muscular manual con diferentes sistemas de graduación, del dinamómetro isocinético, del dinamómetro portátil y del dinamómetro manual. En la práctica clínica, 
la prueba muscular manual con uso de la puntuación motora recomendada por la American Spinal Cord Injury Association fue el método más utilizado, a pesar de las limitaciones destacadas por los fisioterapeutas entrevistados. Conclusión: En las investigaciones científicas, es grande la variación de los métodos e instrumentos utilizados para evaluar la fuerza muscular en sujetos con lesión medular, diferentemente de la práctica clínica. Los instrumentos disponibles y utilizados actualmente presentan importantes limitaciones, que fueron destacadas por los profesionales entrevistados. Ningún instrumento presenta la relación directa de la fuerza muscular con la funcionalidad del sujeto. No hay consenso sobre cuál es el mejor método para evaluar la fuerza muscular en la lesión medular, y son necesarios nuevos instrumentos que sean especificos para su uso en esa población.

Descriptores: Fuerza muscular; Examen físico; Médula espinal.

\section{INTRODUCTION}

Spinal cord injury is a devastating condition that affects thousands of people each year. ${ }^{1}$ In patients with spinal cord injury, muscle atrophy, and loss of strength contribute to the development of disability. Muscle weakness and paralysis limit the performance of functional activities, with decrease in the quality of life..$^{2,3}$

In this context, muscle strength relates to functionality and its evaluation is fundamental in the process of rehabilitation as the first step in defining realistic objectives. ${ }^{3,4}$ The assessment tools used for the patient with spinal cord lesion are mostly similar to those used in other areas of rehabilitation. Few are exclusive. ${ }^{4}$ The cost, the time available for evaluation, and the tolerance of the patients evaluated should be considered in the choosing the technique to be used. Additionally, the choice of the test should take the nervous system to be assessed (autonomic or sensory) into account. In terms of muscle strength, there are different methods that can be both objective, using specific equipment, and subjective. . $^{5,6}$

Despite the importance of evaluation in the rehabilitation process and the recommendations of the American Spinal Injury Association (ASIA), there is no international consensus around which tools should be used in the evaluation of strength in patients with spinal cord injury. ${ }^{7}$ Thus, the objective of this study was to identify the main tools used to evaluate muscle strength through a bibliographical review of studies conducted on spinal cord lesion. We also conducted a survey to characterize the evaluation of muscle strength by physical therapists in clinical practice for subsequent identification of their satisfaction with the tools available in the scientific literature.

\section{METHODS}

This study was approved by the Institutional Review Board of the Universidade Federal de Ciências da Saúde de Porto Alegre as approval number 934.809 (UFCSPA). A search of the PubMed, PEDro, and Virtual Health Library databases was conducted from August 2015 to December 2016. It was performed by two independent investigators, in addition to a third, responsible for reviewing cases of disagreement. The following descriptors were used: spinal cord injury and muscle strength.

Articles published between 1990 and 2016, written in English, Portuguese, and Spanish and conducted with humans that used the endpoints muscle strength of the trunk, lower and/or upper limbs, or manual grip strength to classify the sample, were included. Repeated articles, dissertations, theses, review and validation articles, and those that did not present the complete available text or did not detail the evaluation method used were excluded.

\section{Survey of the data}

The data related to clinical practice for the identification of the satisfaction of professionals who worked with patients suffering from spinal cord injury on a daily basis were collected using a questionnaire with 26 mixed questions prepared by the investigators. The participants were chosen by intentional sampling, The questionnaire was sent by e-mail to 44 physical therapists in the South region of Brazil with experience in neurofunctional physical therapy. They were asked about their academic background and professional experience, their knowledge about muscle strength evaluation tools, their clinical routines, and their opinions about the quality of the muscle strength evaluation tools available. The results were considered using descriptive analysis. We excluded those with inconsistent answers or whose professional information did not report experience in spinal cord injury rehabilitation.

\section{RESULTS}

We found 495 articles, 94 of which were eligible for qualitative analysis. (Figure 1) The following data were extracted: year of publication, authors, tools used, and description of the technique.

Among the studies reviewed (Table 1), forty-two used manual muscle tests, thirty used isokinetic dynamometers, fourteen used portable dynamometers, and two used manual dynamometers. The use of customized tools with load cells or other alternative forms of objective muscle strength evaluation was confirmed in 16 studies. The maximum repetition test was used by three authors. Several authors used a combination of more than one technique.

In the studies that used manual muscle testing (MMT), 11 different tools and scales were identified: ASIA, Kendall, Daniels and Worthinghan, Medical Research Council and its modification, modified Brunnstron and Dennen, OXFORD, and Graded Redefined Assessment of Strength, Sensibility, and Prehension (GRASSP), in addition to unspecified scales.

The MMT tool, recommended by ASIA in the International Classification Standards, with its upper and lower limb motor score was the most frequently cited, found in nineteen studies. (Table 1) The motor scores from this tool evaluate 10 key muscle groups, five of the upper limbs and five of the lower limbs, using a six-point scale in addition to a non-testable (NT) category. ${ }^{4}$

The use of the MMT methodology proposed by Kendall was observed in five works. ${ }^{49,67,75,80,86}$ This method uses a grading system with the introduction of numbers and symbols. The muscles are evaluated individually, with specific positioning for each of them. The choice of which muscles need to be evaluated is made by the examiner. ${ }^{102}$

The Daniels and Worthinghan methodology was used in three studies. ${ }^{12,84,87}$ It also uses a six-point scale for MMT grading, but instead of isolated muscles, it evaluates muscle groups, which should also be determined by the examiner. ${ }^{103}$

Another scale applied to MMT grading is that elaborated by the Medical Research Council, ${ }^{23,50,79,86}$ as well as its variation, ${ }^{83} 96,99$

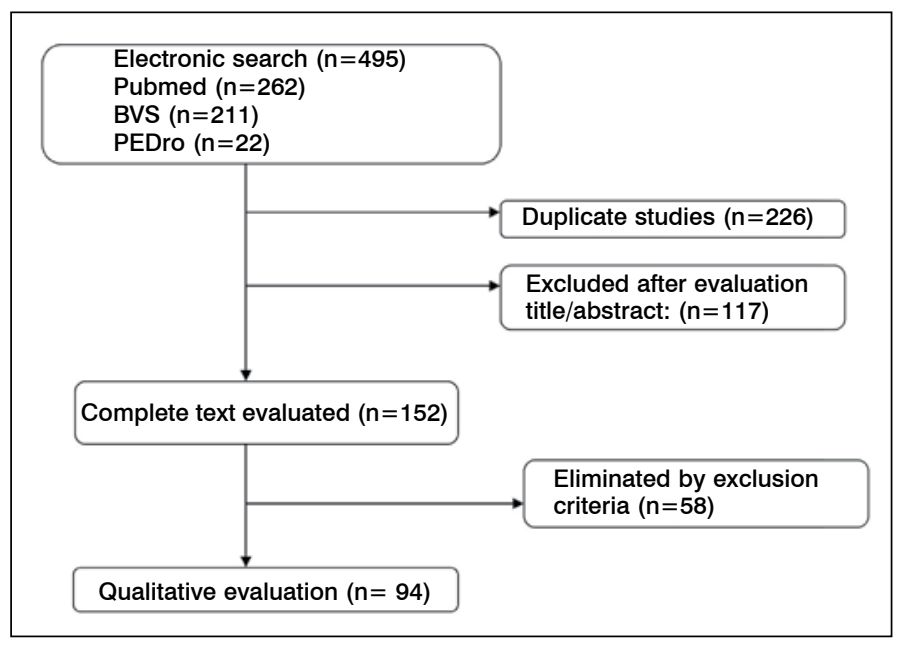

Figure 1. Flowchart of review process. 
Table 1. Instruments used to evaluate muscle strength in scientific research.

\begin{tabular}{|c|c|c|}
\hline Author & Instruments & Method \\
\hline Carrasco-Lopez et al $(2016)^{8}$ & MMT & UEMS \\
\hline Bouton et al. $(2016)^{9}$ & MMT & GRASSP \\
\hline Stevens et al. (2015) ${ }^{10}$ & Portable dynamometer & $\begin{array}{l}\text { Maximum isometric force; one series with a minimum } \\
\text { of three repetitions with } 3 \text { to } 5 \text { s of contraction }\end{array}$ \\
\hline Kim et al. (2015) ${ }^{11}$ & Portable dynamometer & Break-test \\
\hline Senthilvelkumar et al. (2015) ${ }^{12}$ & MMT & Daniels and Worthinghan \\
\hline Gomes-Osman; Field-Fote $(2015)^{13}$ & Manual dynamometer & Average of three repetitions \\
\hline Mulroy et al. $(2015)^{14}$ & Isokinetic dynamometer & $\begin{array}{c}\text { one series of two repetitions of } 5 \mathrm{~s} \text { of contraction, } \\
\text { with } 15 \text { seconds of rest between them }\end{array}$ \\
\hline \multirow[b]{2}{*}{ Dipiro et al (2015) ${ }^{15}$} & MMT & LEMS \\
\hline & Isokinetic dynamometer & $\begin{array}{l}\text { Maximum isometric contraction: three repetitions } \\
\text { with } 5 \text { s duration and } 60 \text { s of rest between them }\end{array}$ \\
\hline Duffell; Brown; Mirbagheri (2015) ${ }^{16}$ & Isokinetic dynamometer & Two repetitions of maximum isometric contraction \\
\hline Bravo-Esteban et al. $(2014)^{17}$ & Isokinetic dynamometer & $\begin{array}{l}\text { Isometric contractions with duration of } \\
5 \mathrm{~s} \text {, five cycles of isotonic contraction; } \\
10 \text { cycles of isokinetic contraction }\end{array}$ \\
\hline Chu; Hornby; Schmit (2014) $)^{18}$ & Isokinetic dynamometer & $\begin{array}{l}\text { Isometric contractions: eight repetitions with } \\
\text { duration of } 5 \mathrm{~s} \text { and rest of } 25 \mathrm{~s} \text { between them }\end{array}$ \\
\hline Jarocha et al. $(2015)^{19}$ & MMT & Lovett Scale \\
\hline Esclarín-Ruz et al. $(2014)^{20}$ & MMT & LEMS \\
\hline Backus et al. $(2014)^{21}$ & AMES device & $\begin{array}{l}\text { six voluntary maximum contractions (three for extension } \\
\text { and three for flexion). Average peak torque calculated }\end{array}$ \\
\hline Fleerkotte et al $(2014)^{22}$ & MMT & LEMS \\
\hline \multirow{2}{*}{ Guiraud et al. $(2014)^{23}$} & MMT & MRC \\
\hline & Isokinetic dynamometer & Maximum isometric contraction \\
\hline Kalsi-Ryan et al. $(2014)^{24}$ & MMT & GRASSP \\
\hline Gabison et al. $(2014)^{25}$ & Portable dynamometer & $\begin{array}{c}\text { one series of three repetitions of } 5 \mathrm{~s} \text {, } \\
\text { with rest of } 30 \text { s between them }\end{array}$ \\
\hline Van Straaten et al. $(2014)^{26}$ & Adapted load cells & $\begin{array}{l}\text { one series of two and three voluntary maximum } \\
\text { isometric contractions with duration of } 3 \text { to } 5 \text { s each }\end{array}$ \\
\hline Froelich-Grobe et al. $(2014)^{27}$ & $1 \mathrm{RM}$ & Maximum voluntary contraction \\
\hline Rosety-Rodriguez et al. $(2014)^{28}$ & Manual dynamometer & $\begin{array}{l}\text { Maximum grip strength measured in one series of } \\
\text { three repetitions with an interval of 90s between them }\end{array}$ \\
\hline Dost et al. $(2014)^{29}$ & Isokinetic dynamometer & five maximum voluntary contractions \\
\hline Triolo et al. $(2013)^{30}$ & Isokinetic dynamometer & $\begin{array}{l}\text { Isometric contractions: eight repetitions with } \\
\text { duration of } 5 \mathrm{~s} \text { and rest of } 25 \mathrm{~s} \text { between them }\end{array}$ \\
\hline Labruyere; Zimmerli; Van Hedel $(2013)^{31}$ & MMT & LEMS \\
\hline Fornusek; Davis; Russold (2013) ${ }^{32}$ & Isokinetic dynamometer & $\begin{array}{c}\text { one series of three isometric contractions with } \\
\text { duration of } 7 \mathrm{~s} \text {, with interval of } 10 \mathrm{~s} \text { between them }\end{array}$ \\
\hline \multirow[b]{2}{*}{ Yeoun-Seung Kang et al. $(2013)^{33}$} & MMT, & UEMS \\
\hline & $\begin{array}{l}\text { Dynamometer customized with } \\
\text { force transducer }\end{array}$ & $\begin{array}{l}\text { Maximum voluntary contraction, } \\
\text { average of } 3 \text { repetitions }\end{array}$ \\
\hline Thompson; Hornby $(2013)^{34}$ & MMT & LEMS \\
\hline \multirow{2}{*}{ Jayaraman et al. $(2013)^{35}$} & MMT & LEMS \\
\hline & Isokinetic dynamometer & $\begin{array}{l}\text { Maximum voluntary isometric } \\
\text { contraction: three repetitions }\end{array}$ \\
\hline Cortes et al. $(2013)^{36}$ & MMT & UEMS \\
\hline Sadowsky et al. $(2013)^{37}$ & Isokinetic dynamometer & Maximum voluntary contraction: five repetitions \\
\hline Lindberg et al. $(2012)^{38}$ & $\begin{array}{l}\text { Piezoelectric force sensor coupled } \\
\text { to customized ergometer }\end{array}$ & $\begin{array}{l}\text { Peak strength in the last } 60 \text { seconds of } \\
\text { the maximum and submaximum test }\end{array}$ \\
\hline Triolo Etal. $(2012)^{39}$ & Isokinetic dynamometer & $\begin{array}{l}\text { Average peak torque of } 12 \text { repetitions } \\
\text { with } 15 \text { s interval between them }\end{array}$ \\
\hline Nooijen et al. $(2012)^{40}$ & Portable dynamometer & Break-test \\
\hline \multirow[b]{2}{*}{ Wu et al. $(2012)^{41}$} & MMT & LEMS \\
\hline & Isokinetic dynamometer & $\begin{array}{c}\text { Average maximum voluntary torque, } \\
\text { without methodology details }\end{array}$ \\
\hline Trumbower et al. $(2012)^{42}$ & Isokinetic dynamometer & $\begin{array}{l}\text { three maximum voluntary contractions, with } 3 \text { to } \\
6 \mathrm{~s} \text { of duration, and } 1 \text { minute of rest between them }\end{array}$ \\
\hline Sledziewski; Schaaf; Mount (2012) & MMT & UEMS \\
\hline Alcobendas-Maestro et al. $(2012)^{44}$ & MMT & LEMS \\
\hline Zijdewind et al. $(2012)^{45}$ & Customized dynamometer with force transducer & $\begin{array}{l}\text { Maximum contraction, maintained for } \\
\text { 5s. Combined contractions } 5 \mathrm{~s} \text {, with } 1 \\
\text { minute of rest between them }\end{array}$ \\
\hline Serra-Añó et al. $(2012)^{46}$ & Isokinetic dynamometer & $\begin{array}{l}\text { six series of three repetitions with duration } \\
\text { of } 5 \mathrm{~s} \text {, and } 30 \text { s of interval between them }\end{array}$ \\
\hline Serra-Añó et al. $(2012)^{47}$ & Isokinetic dynamometer & $\begin{array}{l}\text { one series of three isometric contractions of } 5 \mathrm{~s} ; 30 \mathrm{~s} \\
\text { of rest between them. } 3 \text { minutes of rest, } 5 \text { repetitions } \\
\text { of concentric contractions at different velocities }\end{array}$ \\
\hline Boland et al. $(2011)^{48}$ & MMT & LEMS; UEMS + thumb abductor \\
\hline Johnston et al. $(2011)^{49}$ & Isokinetic dynamometer & three repetitions; 2 minutes of rest between them \\
\hline Yang et al. $(2011)^{50}$ & MMT & Kendall \\
\hline Lundell et al. $(2011)^{51}$ & MMT & MRC \\
\hline Harvey et al. $(2011)^{52}$ & MMT & GRASSP - strength subtest \\
\hline \multirow{2}{*}{ Saraf et al. $(2010)^{53}$} & MMT & LEMS \\
\hline & Isokinetic dynamometer & Maximum voluntary contraction maintained for 2 to $5 \mathrm{~s}$ \\
\hline Larson et al. ( 2010) $)^{54}$ & Portable dynamometer & $\begin{array}{l}\text { Maximum voluntary contraction from one series of } \\
\text { three repetitions, with interval of } 15 \text { s between them }\end{array}$ \\
\hline
\end{tabular}




\begin{tabular}{|c|c|}
\hline Harvey et al. $(2010)^{55}$ & Isokinetic dynamometer \\
\hline Valent et al. $(2009)^{56}$ & Portable dynamometer \\
\hline Glinsky et al. $(2009)^{57}$ & Load cell with visual feedback \\
\hline Bowden Stokic (2009)58 & MMT \\
\hline Rudhe: Van Hedel $(2009)^{59}$ & MMT \\
\hline Jacobs $(2009)^{60}$ & $1 \mathrm{RM}$ \\
\hline Beekhuizen; Field-Fote $(2008)^{61}$ & Portable dynamometer \\
\hline Glinsky et al. $(2008)^{62}$ & Load cells \\
\hline Haisma et al. $(2008)^{63}$ & Portable dynamometer \\
\hline Kern et al. $(2008)^{64}$ & Customized force transducers \\
\hline Johnston et al $(2008)^{65}$ & Isokinetic dynamometer \\
\hline
\end{tabular}

Wirth; Van Hedel; Já; Curt (2008) ${ }^{66}$

Customized force transducers

Wirth; Van Hedel; Já; Curt (2008) ${ }^{67}$

\begin{tabular}{|c|c|}
\hline \multirow{2}{*}{ De Groot et al. $(2008)^{68}$} & MMT \\
\hline & Portable dynamometer \\
\hline Jayaraman et al. $(2008)^{69}$ & Isokinetic dynamometer \\
\hline Gregory et al. $(2007)^{70}$ & Isokinetic dynamometer \\
\hline Liu et al. $(2007)^{71}$ & Isokinetic dynamometer \\
\hline Widman et al. $(2007)^{72}$ & Isokinetic dynamometer \\
\hline Haisma et al. $(2007)^{73}$ & Portable dynamometer \\
\hline Amanda Liussuwan et al. $(2007)^{74}$ & Isokinetic dynamometer \\
\hline Van Drogelen et al. $(2006)^{75}$ & MMT \\
\hline Wirz et al. $(2006)^{76}$ & MMT \\
\hline Javiere et al. $(2006)^{77}$ & Weights and pulleys \\
\hline Rittweger et al. $(2006)^{78}$ & Customized dynamometer \\
\hline Norton; Gorassini $(2006)^{79}$ & MMT \\
\hline \multirow{2}{*}{ Haisma et al. (2006) ${ }^{80}$} & MMT \\
\hline & Portable dynamometer \\
\hline Jayaraman et al. $(2006)^{81}$ & Isokinetic dynamometer \\
\hline Bjerkefors; Jansson, Thorstensson $(2006)^{82}$ & Isokinetic dynamometer \\
\hline Warms et al.(2004) ${ }^{83}$ & Portable dynamometer \\
\hline Mulcahey et al. $(2004)^{84}$ & MMT \\
\hline Kim; Whittaker $(2004)^{85}$ & MMT \\
\hline Bryden Et A L $(2004)^{86}$ & MMT \\
\hline Beninato; O'kane; Sullivan (2004) ${ }^{87}$ & MMT \\
\hline Hicks et al. $(2003)^{88}$ & $1 \mathrm{RM}$ \\
\hline Diego et al. $(2002)^{89}$ & MMT \\
\hline Smith; Mulcahey; Betz $(2001)^{90}$ & MMT \\
\hline Jacobs; Nash; Rusinowski (2001) ${ }^{91}$ & Isokinetic dynamometer \\
\hline Harvey et al. $(2001)^{92}$ & $\begin{array}{l}\text { Pinch strength with modified transducer } \\
\text { Grip strength with various objects }\end{array}$ \\
\hline Belanger et al. $(2000)^{93}$ & Isokinetic dynamometer \\
\hline Kuz; Van Heest; House (1999) ${ }^{94}$ & MMT \\
\hline \multirow{2}{*}{ Thomas et al. $(1998)^{95}$} & MMT \\
\hline & Customized force transducer \\
\hline Noreau; Vachon (1998) ${ }^{96}$ & $\begin{array}{l}\text { MMT } \\
\text { Portable dynamometer } \\
\text { Isokinetic dynamometer }\end{array}$ \\
\hline \multirow[b]{2}{*}{ Herbison et al. (1996) ${ }^{97}$} & MMT \\
\hline & Portable dynamometer \\
\hline Signorile et al. $(1995)^{98}$ & Customized force transducer \\
\hline Kornsgold et al. (1994) ${ }^{99}$ & MMT \\
\hline \multirow{2}{*}{ Granat et al.(1993) 100} & MMT \\
\hline & Customized dynamometer \\
\hline Crozier et al. $(1992)^{101}$ & MMT \\
\hline
\end{tabular}

Best of sis attempts at one RM, with 1 minute of rest between them break-test

Maximum isometric contraction, measured

in 1 series of 8 contractions of $4 \mathrm{~s}$, with

1 minute of rest between them. Average of the three best measurements LEMS, UEMS UEMS, GRASSP

Mayhew regression equation

One average of five repetitions

Measurement of maximum voluntary isometric orque. one series of eight contractions with duration of $4 \mathrm{~s}$, and 1 minute of interval between them Break- test

Measurement of maximum voluntary isometric contraction

three repetitions with 2 minutes between them Maximum voluntary contraction. Peak torque was measured when the subjects were able to maintain the contraction for 2 seconds Maximum voluntary contraction. Peak torque was measured when the subjects were able to maintain the contraction for 2 seconds Kendall Break test

Maximum isometric contraction, measured in one series of three repetitions, with interval of $5 \mathrm{~s}$ between them

Maximum voluntary contraction measured in three repetitions, with 60 s of rest between them Average of five maximum voluntary isometric contractions

Maximum voluntary contraction: repetitions Break- test

Maximum voluntary contraction: three repetitions Kendall

LEMS

Time to complete 20 repetitions with 70\% 1 RM

Measurement of maximum voluntary contraction MRC

Kendall

Break test

Maximum isometric contraction, measured in one series of three repetitions

4 maximum contractions, with rest of 4 s between

them. 2 minutes of rest between each series Noreau and Vachon modified MRC Daniels and Worthinghan

Modified Brunnstron and Denenn; LEMS Kendall; MRC

Daniels and Worthinghan

Test of one repetition with maximum load Scale from 0 to 5

Scale from 0 to 5

Concentric and eccentric contractions: average of three repetitions

Average of three repetitions; Cylinders of different sizes and weights

Maximum voluntary isometric contraction; duration of $2 \mathrm{~s}$, measured every $5 \mathrm{~s}$ in an interval of 4 minutes Scale from 0 to 5 UEMS

Maximum voluntary contraction Modified MRC

Maximum voluntary contraction, one series of three repetitions: 10 seconds of rest between them.

Maximum voluntary contraction: one series of three repetitions; 10 seconds of rest between them

Modified Brunnstron and Denenn.

one series of three repetitions with duration of

1 to $2 \mathrm{~s}$ of maximum voluntary contraction Measurement of maximum voluntary contraction Modified MRC, UEMS

Oxford Scale

Maximum voluntary contraction: best of three repetitions Brunnstron e Dennen 
which grades strength on a scale of 0 to 5 . It does not define the resistance that must be applied by the examiner at the time of the test, nor does it consider the range of motion developed. ${ }^{104}$ In its modified version, the scale was increased by 1.2 points between the degrees of strength.

Application of the motor subtest of the GRASSP tool was confirmed in four studies. 9,24,51,58 It evaluates the upper limbs through MMT on a scale of six points. ${ }^{26}$

The modified Brunstron and Dennem grading scale was applied in three studies. ${ }^{85,97,101}$ This method evaluates, through MMT, not only isolated muscles, but also active movement. ${ }^{102}$ It also uses a six-point scale, with half point between the grades in the modified version. $85,97,101$

The OXFORD scale for the assessment of muscle strength was identified in one study. ${ }^{100}$ Unspecified scales with scoring from 0 to 5 were used in three studies. ${ }^{89,90,94}$ These scales use six-point grading with the force of gravity as a reference of resistance to movement. 100

As regards the survey about strength assessment in clinical practice, 42 of the 44 questionnaires sent were returned. Of these, two were excluded for inconsistency in the responses. In relation to academic background, $22.5 \%$ had masters or doctoral degrees and $32.5 \%$ had specialization in neurofunctional physical therapy. As for professional experience, $52.5 \%$ had worked with neurological patients for more than five years and $42.5 \%$ had more than five years of experience in rehabilitation of spinal cord injury.

In terms of their professional knowledge about the assessment of muscle strength, the physical therapists reported knowing various different methods. The manual muscle test was the most popular and known by all, followed by the manual dynamometer known by $75 \%$, and the isokinetic dynamometer and maximum repetition test by $67.5 \%$. The least remembered was the portable dynamometer, with only $3 \%$. As regards the techniques and muscle strength grading scales used in spinal cord lesions, the ASIA motor score was the best known, followed by the Kendall methodology, identified by $65 \%$ of the professionals.

In clinical practice, 95\% evaluated muscle strength in patients with spinal cord injury during routine sessions. Moreover, for $100 \%$ of the participating physical therapists, the principal objective of strength assessment in these cases was planning the intervention. The most used method was the manual muscle test, used by all those who evaluate muscle strength. The tool used varied, but the motor score recommended by ASIA was the most frequently used (75\%).

Although MMT was used by most of them for clinical evaluation, when questioned about the quality of the MMT tools and scales available, 65\% answered that they did not meet the needs for assessment of patients with spinal cord injury. Among the limitations are the lack of sensitivity in the grading of the scales (30\%), the recommended positioning (25\%), the muscle groups tested (10\%), and the lack of practicality for their application (10.17\%).

\section{DISCUSSION}

In order to choose the best method for assessing muscle strength, the context and the goal of the evaluation, as well as the modality available to the patient, need to be considered. 2,5,6 In patients with neurological impairment, it is important that the muscle strength evaluation be made in comparison to the best expected outcome, given the motor deficit of the patient, and not by comparing the outcome with the pattern of movement expected in patients without injury. ${ }^{2}$

This study revealed that MMT is the most commonly used muscle strength evaluation method in spinal cord injuries, both in clinical practice and in scientific research. MMT is an inexpensive examination method that provides information not only about muscle strength, but also about the extent of the nerve injury and the pattern of movement that it generates. In the muscle function test, not only a test of the strength of a muscle or group of muscles is conducted, but also an assessment of the pattern of movement developed by the patient, ${ }^{105}$ which is important for the evaluation of the neurological patient. However, the survey showed the interviewees' dissatisfaction with the limitations of the MMT tools available in clinical practice. The lack of specific scales for spinal cord injury results makes standardization of the evaluations impossible. Moreover, the available scales do not show a direct relationship between the results and the functionality of the patient. Thus, the limitations of the currently available tools for MMT evaluation need to be resolved.

We identified a large variety of tools and scales in scientific studies using MMT in the evaluation of patients with spinal cord injury. Although most of the studies used the methodology recommended by ASIA, some studies used scales modified for evaluation using manual muscle testing that are not specific and not recommended for assessing spinal cord injury, such as the MRC or modified MRC scale with $1 / 2$ point between each level. ${ }^{104}$

In clinical practice, it has already been confirmed that most physical therapists follow ASIA's recommendation of the use of MMT, in spite of their dissatisfaction with the significant limitations of the tool, such as, for example, the muscle groups evaluated and the suggested positioning. The assessment of motor function through this score only considers five muscle groups for upper limbs and five for lower limbs, representing the C5 to $\mathrm{T} 1$ and $\mathrm{L} 1$ to $\mathrm{S} 1$ myotomes. The trunk muscles are not mandatorily evaluated, though an abdominal function test is suggested. ${ }^{6}$ Thus, any recovery of motor function below $\mathrm{T} 1$ is not recorded, causing a "ceiling" effect on the resulting score that mostly impacts the assessment of cervical injuries. ${ }^{82}$ Another limitation cited in the literature is that this motor evaluation would not be related to patient functionality. ${ }^{8}$ As for psychometric properties, some authors showed strong intra- and inter-examiner reliability with the tool indicated by ASIA for motor evaluation, ${ }^{105}$ while others noted that the motor score presents convergent and divergent construct validity, but suggest that more studies be conducted for the psychometric evaluation of this tool. ${ }^{105}$

The main difference between using manual muscle testing and the other techniques identified, like that proposed by Kendall or the motor score defined by ASIA, is the limitation of the muscles evaluated and the position for the test. In the other techniques used for manual muscle testing, the position for evaluation of each muscle group varies between supine, prone, and lateral. Each muscle is evaluated individually. The muscles are evaluated with the patient always in the supine position. In this position, gravity is eliminated in the evaluation of muscle strength grade $1 / 5$ in the upper limbs, but not in grade 1/5 in the lower limbs. ${ }^{106}$

Another frequently used MMT method identified here was that developed by the Medical Research Council (MRC). Its scale does not define how much resistance must be applied by the examiner at the time of the test, an aspect principally relevant to distinguishing between grades 4 and 5 . The division offered between these two grades (moderate, low, and high resistance) is descriptive and its real meaning is not clear, remaining at the discretion of the examiner. ${ }^{102}$ The range of motion in which the assessment should be conducted is not considered in the MRC scale.

MMT was originally developed by a physician and professor in the Orthopedic Surgery Department of Harvard Medical School, Dr. Lovett, and described by Dr. Wilhelmina Wright in 1912. Lovett created a graduated scale for muscle strength considering gravity as resistance. ${ }^{103}$ Several other grading systems were developed based on this. Nevertheless, while its variations are being constantly revised and perfected by various authors, the factors of weight and movement established by Lovett continue to be the basis for most current tests and scales. ${ }^{102}$

When first developed, MMT was designed for the assessment of victims of poliomyelitis, but currently it is used in different populations, such as patients with spinal cord injury, with greatly differing characteristics. In the literature, there are results published from strength tests based on specific populations, such as athletes or the elderly, and some scales are focused on defined pathologies, such as Duchenne muscular dystrophy. The great variation in the particular characteristics of different populations makes modifications to the systems that grade the results obtained in manual muscle testing necessary. ${ }^{101}$

Objective measurements, like the dynamometer, are needed for their precision. Studies have found that, while manual muscle testing results reach a plateau, in evaluations with the portable dynamometer strength values continue to increase. ${ }^{5}$ Many studies have confirmed the use of equipment like the isokinetic dynamometer and the portable dynamometer, especially more recently. However, their use is not easy to apply. They are not always available due to the high cost, which 
decreases their frequency of use and can be a justification for opting for customized objective assessment tools.

The isokinetic dynamometer also presents limitations when used to evaluate very weak musculatures, which are common in spinal cord lesions. ${ }^{2}$ In addition, even though the portable dynamometer is easy to manipulate and can be used in various environments, the isometric strength measured by it may be influenced by the resistance applied by the evaluator and their ability to keep the device in a stable position, perpendicular to the segment being tested. The correct usage of the portable dynamometer requires more time for positioning than manual muscle testing. ${ }^{5}$ For this reason, muscle strength is most often evaluated without the use of special equipment and inferred through manual muscle testing. ${ }^{6}$

Thus, there is still a lack of global consensus around evaluation methods and the use of standardized scales to assess muscle strength. New tools should try to resolve the restrictions of use identified by professionals, seeking to approximate the theory of clinical practice, and associating the evaluation results with patient functionality. After identifying the limitations and restrictions in the current tools, this study should go on to create a new tool for manual evaluation of muscle strength in patients with spinal cord injury for clinical practice.

Limitations of this review include the exclusion of articles not indexed in the databases consulted and the lack of a critical evaluation of the studies reviewed.

\section{CONCLUSIONS}

There are different ways of evaluating muscle strength in patients with spinal cord injury. None of the methods identified by this review demonstrated a relationship between assessed muscle strength and patient functionality, an important finding both in research and in clinical practice.

Given this, this study showed the need for new studies focused on the development of specific methodologies for the standardized evaluation of these patients.

Todos os autores declaram não haver nenhum potencial conflito de interesses referente a este artigo.

CONTRIBUIÇÕES DOS AUTORES: Cada autor contribuiu individual e significativamente para o desenvolvimento do manuscrito. TVC e FC foram os principais contribuintes na elaboração do manuscrito. RS e FC foram as responsáveis pela orientação metodológica do estudo. RS avaliou os dados da análise estatística. TVC, JSB, FZ e MG realizaram a pesquisa bibliográfica, a pesquisa de satisfação dos profissionais da área e contribuíram para o conceito intelectual do estudo.

\section{REFERÊNCIAS}

1. Rahimi-MovagharV Sayyah MK, Akbari H, Khorramirouz R, Rasouli MR, Moradi-Laken M, et al. Epidemiology of traumatic spinal cord injury in developing countries: a systematic review. Neuroepidemiology. 2013;41(2): 65-85.

2. Harvey L. Management of spinal cord injuries: a guide for physiotherapists. Elsevier Health Sciences; 2008.

3. Beninato M, O'Kane KS, Sullivan PE. Relationship between motor FIM and muscle strength in lower cervical-level spinal cord injuries.Spinal Cord. 2004;42(9):533-40.

4. Harvey LA. Physiotherapy rehabilitation for people with spinal cord injuries.J Physiother 2016;62(1):4-11

5. Noreau L, Vachon J. Comparison of three methods to assess muscular strength in individuals with spinal cord injury. Spinal Cord. 1998;36(10):716-23

6. Ellaway PH, Kuppuswamy A, Balasubramaniam AV, Maksimovic R, Gall A, Craggs MD, et al Development of quantitative and sensitive assessments of physiological and functional outcome during recovery from spinal cord injury: a clinical initiative. Brain Res Bull. 2011;84(4):343-57.

7. Alexander MS, Anderson KD, Biering-Sorensen F, Blight AR, Brannon R, Bryce TN, et al. Outcome measures in spinal cord injury: recent assessments and recommendations for future directions. SpinalCord. 2009;47(8):582-91.

8. Carrasco-López C, Jimenez S, Mosqueda-Pozon MC, Pérez-Borrego YA, Alcobendas-Maestro $\mathrm{M}$, Gallego-Izquierdo T, et al. New insights from clinical assessment of upper extremities in cervical traumatic spinal cord injury. J Neurotrauma. 2016;33(18):1724-7.

9. Bouton CE, Shaikhouni A, Annetta NV, Bockbrader MA, Friedenberg DA, Nielson DM, et al. Restoring cortical control of functional movement in a human with quadriplegia. Nature. 2016:533(7602):247-50.

10. Stevens SL, Caputo JL, Fuller DK, Morgan DW. Effects of underwater treadmill training on leg strength, balance, and walking performance in adults with incomplete spinal cord injury. JSpinal Cord Med. 2015:38(1):91-101.

11. Kim DI, Lee H, Lee BS, Kim J, Jeon JY. Effects of a 6-week indoor hand-bike exercise program on health and fitness levels in people with spinal cord injury: a randomized controlled trial study. Arch Phys Med Rehabil. 2015;96(11):2033-40.

12. Senthilvelkumar T, Magimairaj H, Fletcher J, Tharion G, George J. Comparison of body weightsupported treadmill training versus body weight-supported overground training in people with incomplete tetraplegia: a pilot randomized trial. Clin Rehabil. 2015;29(1):42-9.

13. Gomes-Osman J, Field-Fote EC. Improvements in hand function in adults with chronic tetraplegia following a multi-day $10 \mathrm{~Hz}$ rTMS intervention combined with repetitive task practice. J Neurol PhysTher. 2015;39(1):23-30.

14. Mulroy SJ, Hatchett P, Eberly VJ, Haubert LL, Conners S, Requejo PS. Shoulder strength and physical activity predictors of shoulder pain in people with paraplegia from spinal injury: prospective cohort study. PhysTher. 2015;95(7):1027-38.

15. DiPiro ND, Holthaus KD, Morgan PJ, Embry AE, Perry LA, Bowden MG, et al. Lower Extremity Strength Is Correlated with Walking Function After Incomplete SCI. Top Spinal Cord Inj Rehabil. 2015;21(2):133-9.

16. Duffell LD, Brown GL, Mirbagheri MM. Facilitatory effects of anti-spastic medication on robotic locomotor training in people with chronic incomplete spinal cord injury. J Neuroeng Rehabil. 2015; 12:29.

17. Bravo-Esteban E, Taylor J, Aleixandre M, Simon-Martínez C, Torricelli D, Pons JL, et al. Tibialis Anterior muscle coherence during controlled voluntary activation in patients with spinal cord injury: diagnostic potential for muscle strength, gait and spasticity. J Neuroeng Rehabil. 2014:11:23.

18. Chu WW, Hornby TG, Schmit BD. Effect of antispastic drugs on motor reflexes and voluntary muscle contraction in incomplete spinal cord injury. Arch Phys Med Rehabil. 2014;95(4):622-32.

19. Jarocha D, Milczarek O, Wedrychowicz A, Kwiatkowski S, Majka M. Continuous improvement after multiple mesenchymal stem cell transplantations in a patient with complete spinal cord injury. Cell Transplant. 2015;24(4):661-72.

20. Esclarín-Ruz A Alcobendas-Maestro M, Casado-Lopez R, Perez-Mateos G, Florido-Sanchez MA, Gonzalez-Valdizan $\mathrm{E}$, et al. A comparison of robotic walking therapy and conventiona walking therapy in individuals with upper versus lower motor neuron lesions: a randomized controlled trial. Arch Phys Med Rehabil. 2014;95(6):1023-31.

21. Backus D, Cordo P, Gillott A, Kandilakis C, Mori M, Raslan AM. Assisted movement with proprioceptive stimulation reduces impairment and restores function in incomplete spinal cord injury. Arch Phys Med Rehabil. 2014;95(8):1447-5322.

22. FleerkotteBM, Koopman B, Buurke JH, van Asseldonk EH, van der Kooij H, Rietman JS. The effect of impedance-controlled robotic gait training on walking ability and quality in individuals with chronic incomplete spinal cord injury: an explorative study. J Neuroeng Rehabil. 2014;11:26

23. Guiraud D, Azevedo Coste C. Benoussaad M. Fattal C. Implanted functional electrical stimulation: case report of a paraplegic patient with complete SCI after 9 years. J Neuroeng Rehabil. 2014;11:15

24. Kalsi-Ryan S, Beaton D, Curt A, Duff S, Jiang D, Popovic MR, et al. Defining the role of sensation, strength, and prehension for upper limb function in cervical spinal cord injury. NeurorehabilNeural Repair. 2014;28(1):66-74

25. Gabison S, Verrier MC, Nadeau S, Gagnon DH, Roy A, Flett HM. Trunk strength and function using the multidirectional reach distance in individuals with non-traumatic spinal cord injury. $J$ Spinal Cord Med. 2014;37(5):537-47.

26. Van Straaten MG, Cloud BA, Morrow MM, Ludewig PM, Zhao KD. Effectiveness of home exercise on pain, function, and strength of manual wheelchair users with spinal cord injury: a high-dose shoulder program with telerehabilitation. Arch Phys Med Rehabil. 2014:95(10):1810-7.

27. Froehlich-Grobe K, Lee J, Aaronson L, Nary DE, Washburn RA, Little TD. Exercise for everyone: a randomized controlled trial of project workout on wheels in promoting exercise among wheelchair users. Arch Phys Med Rehabil.2014;95(1):20-8.

28. Rosety-Rodriguez M, Rosety I, Fornieles G, Rosety JM, Elosegui S, Rosety MA, et al A shortterm arm-crank exercise program improved testosterone deficiency in adults with chronic spinal cord injury. Int Braz J Urol. 2014;40(3):367-72.

29. Triolo RJ, Bailey SN, Miller ME, Lombardo LM, Audu ML. Effects of stimulating hip and trunk muscles on seated stability, posture, and reach after spinal cord injury. Arch Phys Med Rehabil. 2013:94(9):1766-75.

30. Labruyère R, Zimmerli M, van Hedel HJ. Slowed down: response time deficits in well-recovered subjects with incomplete spinal cord injury. Arch Phys Med Rehabil. 2013;94(10):2020-6

31. Fornusek C, Davis GM, Russold MF. Pilot study of the effect of low-cadence functional electrical stimulation cycling after spinal cord injury on thigh girth and strength. Arch Phys Med Rehabil. 2013:94(5):990-3.

32. Yeoun-Seung Kang MD, Lee BS. Biomechanical evaluation of wrist-driven flexor hinge orthosis in persons with spinal cord injury. J Rehabil Res Dev. 2013;50(8):1129-38.

33. Thompson CK, Hornby TG.Divergent modulation of clinical measures of volitional and reflexive motor behaviors following serotonergic medications in human incomplete spinal cord injury.J Neurotrauma. 2013:30(6):498-502.

34. Jayaraman A, Thompson CK, Rymer WZ, Hornby TG. Short-term maximal-intensity resistance training increases volitional function and strength in chronic incomplete spinal cord injury: a pilot study. J Neurol PhysTher. 2013;37(3):112-7.

35. Cortes M, Elder J, Rykman A, Murray L, Avedissian M, Stampas A et al. Improved moto performance in chronic spinal cord injury following upper-limb robotic training. Neuro Rehabilitation. 2013;33(1):57-65.

36. Sadowsky CL, Hammond ER, Strohl AB, Commean PK, Eby SA, Damiano DL, et al. Lower 
extremity functional electrical stimulation cycling promotes physical and functional recovery in chronic spinal cord injury. J Spinal Cord Med. 2013;36(6):623-31.

37. Lindberg T, Arndt A, Norrbrink C, Wahman K, Bjerkefors A. Effects of seated double-poling ergometer training on aerobic and mechanical power in individuals with spinal cord injury. $J$ RehabilMed. 2012:44(10):893-8.

38. Triolo RJ, Bailey SN, Miller ME, Rohde LM, Anderson JS, Davis JA Jr, et al. Longitudinal performance of a surgically implanted neuroprosthesis for lower-extremity exercise, standing, and transfers after spinal cord injury. Arch Phys Med Rehabil. 2012;93(5):896-904.

39. Nooijen CF, de Groot S, Postma K, Bergen MP, Stam HJ, Bussmann JB, et al. A more active lifestyle in persons with a recent spinal cord injury benefits physical fitness and health. Spinal Cord. 2012;50(4):320-3

40. Wu M, Landry JM, Schmit BD, Hornby TG, Yen SC. Robotic resistance treadmill training improves locomotor function in human spinal cord injury: a pilot study. Arch Phys Med Rehabil. 2012:93(5):782-9.

41. Trumbower RD, Jayaraman A, Mitchell GS, RymerWZ. Exposure to acute intermittent hypoxia augments somatic motor function in humans with incomplete spinal cord injury. NeurorehabilNeural Repair. 2012;26(2):163-72.

42. Sledziewski L, Schaaf RC, Mount J. Use of robotics in spinal cord injury: A case report. Am J OccupTher. 2012;66(1):51-8.

43. Alcobendas-Maestro M, Esclarín-Ruz A, Casado-López RM, Muñoz-González A, Pérez-Mateos G, González-Valdizán E, et al. Lokomat robotic-assisted versus overground training within 3 to 6 months of incomplete spinal cord lesion: randomized controlled trial. Neurorehabil Neural Repair 2012:26(9):1058-63.

44. Zijdewind I, Gant K, Bakels R, Thomas CK. Do additional inputs change maximal voluntary motor unit firing rates after spinal cord injury? Neurorehabil Neural Repair. 2012;26(1):58-67.

45. Serra-Añó P, García-Massó X, Pellicer M, González LM, López-Pascual J, Giner-Pascual M, et al. Force Normalization in Paraplegics. Int J Sports Med. 2012;33(0):452-8.

46. Serra-Añó P, Pellicer-Chenoll M, García-Massó X, Morales J, Giner-Pascual M, González LM Effects of resistance training on strength, pain and shoulder functionality in paraplegics.Spinal Cord. 2012;50(11):827-31.

47. Boland RA, Lin CS, Engel S, Kiernan MC. Adaptation of motor function after spinal cord injury: novel insights into spinal shock. Brain. 2011:134(Pt2):495-505.

48. JohnstonTE, Modlesky CM, Betz RR, Lauer RT. Muscle changes following cycling and/or electrical stimulation in pediatric spinal cord injury. Arch Phys Med Rehabil. 2011;92(12):1937-43.

49. Yang JF, Norton J, Nevett-Duchcherer J, Roy FD, Gross DP, Gorassini MA. Volitional muscle strength in the legs predicts changes in walking speed following locomotor training in people with chronic spinal cord injury. Physical Ther. 2011;91(6):931-43.

50. Lundell H, Barthelemy D, Skimminge A, Dyrby TB, Biering-Sørensen F, Nielsen JB. Independent spinal cord atrophy measures correlate to motor and sensory deficits in individuals with spinal cord injury. Spinal Cord. 2011;49(1):70-5.

51. Harvey LA, Dunlop SA, Churilov L, Hsueh YS, Galea MP. Early intensive hand rehabilitation afte spinal cord injury ("Hands On"): a protocol for a randomised controlled trial. Trials. 2011:12:14

52. Saraf P, Rafferty MR, Moore JL, Kahn JH, Hendron K, Leech K, et al. Daily stepping in individuals with motor incomplete spinal cord injury. PhysTher. 2010;90(2):224-35.

53. Larson CA, Tezak WD, Malley MS, Thornton W. Assessment of postural muscle strength in sitting: reliability of measures obtained with hand-held dynamometry in individuals with spinal cord injury. J Neurol PhysTher. 2010:34(1):24-31.

54. Harvey LA, Fornusek C, Bowden JL, Pontifex N, Glinsky J, Middleton JW, et al. Electrical stimulation plus progressive resistance training for leg strength in spinal cord injury: a randomized controlled trial. Spinal Cord. 2010:48(7):570-5

55. Valent LJ, Dallmeijer AJ, Houdijk H, Slootman HJ, Janssen TW, Post MW, et al. Effects of hand cycle training on physical capacity in individuals with tetraplegia: a clinical trial. PhysTher. 2009;89(10):1051-60

56. Glinsky J, Harvey L, van Es P, Chee S, Gandevia SC. The addition of electrical stimulation to progressive resistance training does not enhance the wrist strength of people with tetraplegia: a randomized controlled trial. ClinRehabil. 2009:23(8):696-704.

57. Bowden M, Stokic DS. Clinical and Neurophysiologie Assessment of Strength and Spasticity DuringIntrathecal Baclofen Titration in Incomplete Spinal Cord Injury: Single-Subject Design. J Spinal Cord Med. 2009;32(2):183-90

58. Rudhe C, van Hedel HJ. Upper extremity function in persons with tetraplegia: Relationships between strength, capacity and the spinal cord independence measure. Neurorehabil Neural Repair. 2009;23(5):413-21.

59. PL. Effects of resistance and endurance training in persons with paraplegia. Med ScSports Exerc. 2009:41(5):992-7.

60. Beekhuizen KS, Field-Fote EC. Sensory stimulation augments the effects of massed practice training in persons with tetraplegia. Arch Phys Med Rehabil. 2008:89(4):602-8.

61. Glinsky J, Harvey L, Korten M, Drury C, Chee S, Gandevia SC. Short-term progressive resistance exercise may not be effective at increasing wrist strength in people with tetraplegia: a randomised controlled trial. Aust J Physiother. 2008:54(2):103-8.

62. Haisma JA Post MW van der Woude LH, Stam HJ Bergen MP Sluis TA et al. Functional independence and health-related functional status following spinal cord injury: a prospective study of the association with physical capacity. J Rehabil Med. 2008;40(10):812-8.

63. Kern H, Hofer C, Mödlin M, Mayr W, Vindigni V, Zampieri S, et al. Stable muscle atrophy in long-term paraplegics with complete upper motor neuron lesion from 3-to 20-year SCI. Spinal Cord 2008:46(4):293-304

64. Johnston TE, Smith BT, Oladeji O, Betz RR, Lauer RT. Outcomes of a home cycling program using functional electrical stimulation or passive motion for children with spinal cord injury: a case series. J Spinal Cord Med. 2008;31(2):215-21.

65. Wirth $B$, van Hedel HJ, Curt A. Ankle dexterity remains intact in patients with incomplete spinal cord injury in contrast to stroke patients. Exp Brain Res. 2008;191(3):353-61.

66. Wirth $B$, van Hedel HJ, Curt A. Ankle dexterity is less impaired than muscle strength in incomplete spinal cord lesion. J Neurol. 2008;255(2):273-9.

67. de Groot S, Dallmeijer AJ, Post MW, Angenot EL, van der Woude LH. The longitudinal relationship between lipid profile and physical capacity in persons with a recent spinal cord injury. Spinal Cord. 2008;46(5):344-51.

68. Jayaraman A, Shah P, Gregory C, Bowden M, Stevens J, Bishop M, et al. Locomotor training and muscle function after incomplete spinal cord injury: case series. J Spinal Cord Med. 2008;31(2):185-93

69. Gregory CM, Bowden MG, Jayaraman A, Shah P, Behrman A, Kautz SA, et al. Resistance training and locomotor recovery after incomplete spinal cord injury: a case series. Spinal Cord. 2007; $45(7): 522-30$

70. Liu CW, Chen SC, Chen CH, Chen TW, Chen JJ, Lin CS, et al. Effects of functional electrical stimulation on peak torque and body composition in patients with incomplete spinal cord injury. Kaohsiung J Med Sci. 2007;23(5):232-40.

71. Widman LM, Abresch RT, Styne DM, McDonald CM. Aerobic fitness and upper extremity strength in patients aged 11 to 21 years with spinal cord dysfunction as compared to ideal weight and overweight controls. J Spinal Cord Med. 2007;30(supp1):S88-96.

72. Haisma JA, van der Woude LH, Stam HJ, Bergen MP, Sluis TA, de Groot S, et al. Prognostic models for physical capacity at discharge and 1 year postdischarge from rehabilitation in persons with spinal cord injury. Arch Phys Med Rehabil. 2007;88(12):1694-703.

73. Liusuwan RA, Widman LM, Abresch RT, Johnson AJ, McDonald CM. Behavioral inter vention, exercise, and nutrition education to improve health and fitness (BENEfit) in adolescents with mobility impairment due to spinal cord dysfunction. J Spinal Cord Med 2007:30(supp1):S119-26.

74. van Drongelen S, de Groot S, Veeger HE, Angenot EL, Dallmeijer AJ, Post MW, et al. Upper extremity musculoskeletal pain during and after rehabilitation in wheelchair-using persons with a spinal cord injury. Spinal Cord. 2006;44(3):152-9

75. Wirz M, van Hedel HJ, Rupp R, Curt A, Dietz V. Muscle force and gait performance: relationships after spinal cord injury. Arch Phys Med Rehabil.2006:87(9):1218-22.

76. Javiere C, Vidal J, Segura R, Lizarraga MA, Medina J, Ventura JL. The effect of supplementation wit $n-3$ fatty acids on the physical performance in subjects with spinal cord injury. J Physiol Biochem. 2006;62(4):271-9.

77. Rittweger J, Gerrits KH, Altenburg TM, Reeves ND, Maganaris CN, Haan AD. Bone adaptation to altered loading after spinal cord injury: a study of bone and muscle strength. J. Musculoskelet Neuronal Interact. 2006;6(3):269-76

78. Norton JA, Gorassini MA. Changes in cortically related intermuscular coherence accompanying improvements in locomotor skills in incomplete spinal cord injury. J Neurophysiol. 2006:95(4):2580-9.

79. Haisma JA, Bussmann JB, Stam HJ, Sluis TA, Bergen MP, Dallmeijer AJ, et al. Changes in physical capacity during and after inpatient rehabilitation in subjects with a spinal cord injury. Arch Phys Med Rehabil. 2006;87(6):741-8.

80. Jayaraman A, Gregory CM, Bowden M, Stevens JE, Shah P, Behrman AL, et al. Lower extremity skeletal muscle function in persons with incomplete spinal cord injury. Spinal Cord. 2006;44(11):680-7.

81. Bjerkefors A, Jansson A, Thorstensson A. Shoulder muscle strength in paraplegics before and after kayak ergometer training. Eur J Appl Physiol. 2006;97(5):613-8.

82. Warms CA, Belza BL, Whitney JD, Mitchell PH, Stiens SA. Lifestyle physical activity for individuals with spinal cord injury: a pilot study. Am J Health Promot. 2004;18(4):288-91.

83. Mulcahey MJ, Betz RR, Kozin SH, Smith BT, Hutchinson D, Lutz C. Implantation of the Fre ehand System® during initial rehabilitation using minimally invasive techniques. Spinal Cord. 2004:42(3):146-55

84. Kim CM, Eng JJ, Whittaker MW. Level walking and ambulatory capacity in persons with incomplete spinal cord injury: relationship with muscle strength. Spinal Cord. 2004;42(3):156-62.

85. Bryden AM, Kilgore KL, Lind BB, Yu DT. Triceps denervation as a predictor of elbow flexion contractures in C5 and C6 tetraplegia. Arch Phys Med Rehabil. 2004:85(11):1880-5.

86. Beninato M, O'Kane KS, Sullivan PE. Relationship between motor FIM and muscle strength in lower cervical-level spinal cord injuries.Spinal Cord. 2004;42(9):533-40.

87. Hicks AL, Martin KA, Ditor DS, Latimer AE, Craven C, Bugaresti J, et al. Long-term exercise training in persons with spinal cord injury: effects on strength, arm ergometry performance and psychological well-being. Spinal Cord. 2003:41(1):34-43.

88. Diego MA, Field T, Hernandez-Reif M, Hart S, Brucker B, Field T, et al. Spinal cord patients benefit from massage therapy. Int J Neurosci. 2002;112(2):133-42.

89. Smith BT, Mulcahey MJ, Betz RR. An implantable upper extremity neuroprosthesis in a growing child with a C5 spinal cord injury.Spinal Cord. 2001;39(2):118-23.

90. Jacobs PL, Nash MS, Rusinowski JW. Circuit training provides cardiorespiratory and strength benefits in persons with paraplegia. Med Sci Sports Exerc. 2001;33(5):711-7.

91. Harvey L, Crosbie J. Effect of elbow flexion contractures on the ability of people with $\mathrm{C} 5$ and C6 tetraplegia to lift. Physiother Res Int. 2001;6(2):76-82.

92. Bélanger M, Stein RB, Wheeler GD, Gordon T, Leduc B. Electrical stimulation: can it increase muscle strength and reverse osteopenia in spinal cord injured individuals? Arch Phys Med Rehabil.2000;81(8):1090-8.

93. Kuz JE, Van Heest AE, House JH. Biceps-to-triceps transfer in tetraplegic patients: report of the medial routing technique and follow-up of three cases. J Hand Surg Am. 1999·24(1):161-72.

94. Thomas CK, Tucker ME, Bigland-Ritchie B. Voluntary muscle weakness and co-activation after chronic cervical spinal cord injury. J Neuro trauma. 1998;15(2):149-61.

95. Noreau L, Vachon J. Comparison of three methods to assess muscular strength in individuals with spinal cord injury. Spinal Cord. 1998:36(10):716-23.

96. Herbison GJ, Isaac Z, Cohen ME, Ditunno JF Jr. Strength post-spinal cord injury: myometervs manual muscle test. Spinal Cord. 1996;34(9):543-8.

97. Signorile JF, Banovac K, Gomez M, Flipse D, Caruso JF, Lowensteyn I. Increased muscle strength in paralyzed patients after spinal cord injury: effect of beta-2 adrenergic agonist. Arch Phys Med Rehabil.1995:76(1):55-8.

98. Kornsgold LM, Herbison GJ, Decena BF 3rd, Ditunno JF. Biceps vs extensor carpi radialis recovery in Frankel grades A and B in spinal cord injury patients. Paraplegia. 1994;32(5):340-8.

99. Granat MH, Ferguson AC, Andrews BJ, Delargy M. The role of functional electrical stimulation in the rehabilitation of patients with incomplete spinal cord injury-observed benefits during gait studies. Paraplegia. 1993:31(4):207-15.

100. Crozier KS, Cheng LL, Graziani V, Zorn G, Herbison G, Ditunno JF Jr. Spinal cord injury: prognosis for ambulation based on quadriceps recovery. Paraplegia. 1992;30(11):762-7.

101. Hislop H, Avers D, Brown M. Daniels andWorthingham's muscle testing: Techniques of manual examination and performance testing. Elsevier Health Sciences; 2013.

102. Steeves JD, Lammertse D, Curt A, Fawcett JW, Tuszynski MH, Ditunno JF, et al. Guidelines for the conduct of clinical trials for spinal cord injury (SCI) as developed by the ICCP panel: clinical trial outcome measures. Spinal Cord. 2007;45(3):206-21.

103. Paternostro-Sluga T, Grim-Stieger M, Posch M, Schuhfried O, Vacariu G, Mittermaier C, et al. Reliability and validity of the Medical Research Council (MRC) scale and a modified scale for testing muscle strength in patients with radial palsy. J Rehabil Med. 2008;40(8):665-71.

104. Motor exam Guide.American Spinal Cord Injury Association.Avaialable from: http://asia-spinalinjury.org/learning/ Acesso em junho de 2016.

105. Furlan JC, Fehlings MG, Tator $\mathrm{CH}$, Davis AM. Motor and sensory assessment of patients in clinical trials for pharmacological therapy of acute spinal cord injury: psychometric properties of the ASIA Standards. J Neurotrauma. 2008;25(11):1273-301.

106. Janda V. Muscle function testing. Elsevier; 2013 